\title{
Correction to: Circular Nanocavity in Ultrathin c-Si Solar Cell for Efficient Light Absorption
}

\author{
Sandipta $\operatorname{Roy}^{1}$ (1)
}

Published online: 7 November 2017

(C) Springer Science+Business Media, LLC 2017

\section{Correction to: Plasmonics}

https://doi.org/10.1007/s11468-017-0656-4

The original version of this article unfortunately contained a mistake. Author name Roy Sandipta should read Sandipta Roy.

The online version of the original article can be found at https://doi.org/ 10.1007/s11468-017-0656-4.

$\triangle$ Sandipta Roy

sandipta.r@iitb.ac.in

1 Center for Research in Nanotechnology and Science, Indian Institute of Technology Bombay, Mumbai 400076, India 